\title{
FOOD PRODUCTION AND CONSUMPTION PATTERN AT COASTAL AREA OF KARAMPUANG ISLAND
}

\author{
Sulaiman Teddu ${ }^{1}$, M. Saleh S. Ali ${ }^{*}$, Darmawan Salman² \\ ${ }^{1}$ Graduate School, Hasanuddin University, Makassar, Indonesia. \\ ${ }^{2}$ Department of Social Economics of Agriculture, Faculty of Agriculture, Hasanuddin \\ University, Makassar, Indonesia \\ * Corresponding author e-mail: saleh.assofie@gmail.com
}

Citation: Teddu, S., Ali, M.S.S., Salman, D. 2018. Food Production and Consumption Pattern at Coastal Area of Karampuang Island. J. Asian Rur. Stud. 2(2): 196-204

\begin{abstract}
Patterns of production and consumption of food communities in coastal regions are different from the people who live in mountainous areas or other areas (agricultural society). The fundamental difference between coastal communities and the agricultural society is due to the access to land. This study aimed to assess the patterns of food production and consumption in coastal areas. The method used is a case study to look deeply at the social reality of consumption and production pattern in coastal regions. Field data collection is done systematically through questionnaires, in-depth interviews, focus group discussions and field observation. The focus on research is the coastal community in Karampuang island. The target group is determined based on the knowledge of field conditions, and the initial information has been obtained from key informants. The most important results were obtained, namely: Patterns of food production of the island Karampuang characterized by the production of a limited form of cassava were only able to complement the food needs alone, and Society Consumption Pattern Karampuang Island is characterized by the intensity of the low consumption, low consumption type material variations.
\end{abstract}

Keywords: Food Production; Food Consumption; Coastal Region; West Sulawesi province

\section{Introduction}

The increase in global population has an impact on increasing food consumption (Wan, 2005). This phenomenon brings vulnerability to sustainable production and consumption. The unsustainable food production and consumption brought a global catastrophe (Ahmad, Rahmadanih, \& Ali, 2017; Brizga, Mishchuk, \& GolubovskaOnisimova, 2014). Throughout history, human population has experienced a shortage of food production. Population growth of the past has carried excessive exploitation of natural resources and resulted in the extinction and the collapse of civilization in the history (Diamond, 2005).

Production and consumption of sustainable food are the main challenges to improve the welfare of future generations (Jonkute \& Staniškis, 2016), This challenge is not easy because it faces infrastructure, economy and ecology pressures (Cohen \& Mu, 2015). This has pushed many people, including many academicians to undertake efforts to develop production and consumption of sustainable food (Dubey et al., 2016). 
Sustainable consumption and production (SCP) have become an important topic both concerning policy and research agenda for academics over the last ten years (Geels, Mcmeekin, Mylan, \& Southerton, 2015). Based on the above description, it is necessary to research to assess and explain in depth about food production and consumption patterns of people in coastal areas which are different from that in upland and lake areas (Ahmad et al., 2017; Ali, et el., 2017).

Availability of production to meet urgent food needs, particularly domestic production, because food security is one crucial component of the national security state (Meskhia, 2016). It is that effort does not make the food needs a top priority import. Due to the dependence on food fulfillment from imports, it is very vulnerable both politically and economically (Boucekkine, Prieur, \& Puzon, 2016). Politically, this condition will affect the foreign policy of Indonesia, especially concerning bilateral cooperation. While the export economy to be a burden of the state budget, the higher the volume of exports, the more significant the amount of budget needed.

Governments must implement food policies, namely ensuring food security which includes the supply, diversification, security, institutional and food organization. This policy is needed to increase food self-sufficiency. Self-reliance in development that ignores the basic needs of the population will be highly dependent on other countries, and that means a country that is not sovereign (Arifin, 2004).

Sustainability of food availability is faced with several problems and challenges, one of which is the capacity of food production is increasingly limited due to an increased number of people along with their economic activities that result in the conversion to agricultural land to non-agricultural land, so that the average tenure of agricultural land by farmers become smaller. Most farmers in the countryside, the rural landless or tenant farmers who do not own their land (Menike \& Arachchi, 2016). Obstacles often faced by the farmers to undertake farming process usually are because of limited capital owned, the limited production capacity of causing relatively stagnant farm productivity (Baliwati \& Roosita, 2004).

In contrast to the farmers as an agrarian society that was owning or renting land, fishing is a coastal community has its dynamics. The fundamental difference between coastal communities and the agricultural society is on access to resources (Satria, Matsuda, \& Sano, 2006). Very different from the land resources on an agrarian society, the sea is a natural resource that is open access so anyone can access it. Resources that are open have led to competition among fishers is becoming increasingly hard. Not surprisingly, the fishermen or coastal communities, in general, have a strong character (Salman, 2012; Satria et al., 2006). Especially high-risk jobs of both the safety of life and economic (Salman, 2012; Satria, 2001, 2009). The availability of food for coastal communities is determined by the distribution and access to food provided.

Based on the results of Economic Census 2016 by BPS showed that the total population of 1,282,162 inhabitants of West Sulawesi with a population density of 76 inhabitants $/ \mathrm{km} 2$, as well as the growth rate of $2.68 \%$ per year (BPS, 2016). The high rate of population growth can lead to the conversion of agricultural land into agricultural land and non-agricultural others to meet the needs of the population, such as for housing and other economic purposes. 
Mamuju is one of six districts in West Sulawesi and has an area of 15395 hectares of rice acreage with a productivity of 4.97 tonnes per hectare, and total production amounted to 108225 tons (BPS, 2016). Based on the results of the National Economic Census 2016 Percentage of Per Capita Expenditure by Type A month expenditure group that is dominated Rp 100,000 - Rp. 499.000 by $65.56 \%$. This indicates that the number of people whose food needs are limited fulfillment capabilities is very high. Because one of the factors that influence food consumption is a budget allocation (Osman, Osman, Mokhtar, \& Setapa, 2014).

Based on the description of, it appears that the limiting factors of production such as land and fishing areas in coastal areas allowing the inability to produce food independently, to meet the needs of highly vulnerable food consumption. Also, the food supply of rural producers also allows disconnecting because the infrastructure is insufficient and long distance. The purpose of this study was to analyze patterns of production and consumption patterns of coastal communities from an institutional perspective.

\section{Method}

This study uses a case study to look deeply into the social reality of consumption and production in coastal areas. Field data collection is done systematically through questionnaires and in-depth interviews. Furthermore, this research is characterized by a focus group discussions and field observations to understand better the real conditions that occur. Primary data collected to include the type of commodities that are cultivated, the cause of the selection of the commodity, the kinds of food that is consumed, the amount of food consumed, causes selecting food commodities, vast land tenure, the types of community work in the research area, the intensity of public consumption. As for the secondary data obtained from documents relevant agencies or institutions such as the Food Security Office of Mamuju, Agriculture and Livestock Mamuju and all related information to the research area. The target group is determined based on the knowledge of field conditions, and the initial data has been obtained from key informants. The coastal communities of Karampuang island in Mamuju regency West Sulawesi province has been selected as the unit case of the grounds. The criteria used for selection were 1) the ability of communities to meet the needs of food is insufficient, a factor of production is very limited since the geography of the island that is not suitable for agriculture, 2) some people do a circular migration to Mamuju city in order to meet household needs including food.

This study uses qualitative data analysis techniques to assess and describe patterns of production and consumption of food, value and knowledge, accessibility and behavior, adaptation consumption and food production as well as the institutional role of consumption and food production in coastal areas.

\section{Research Site}

Karampuang Island is a village located in Mamuju district Mamuju regency in West Sulawesi province. Karampuang island situated in the Gulf between Mamuju with an area of $6.37 \mathrm{~km} 2$, Karampuang hilly topography, and rocky island because it comes from the volcanic island. Detailed land used Karampuang Island consists of moor 149 hectares, yard area of 33 hectares, plantations covering an area of 62 hectares and 
protected forest area of 6 hectares. Karampuang island topography ranges from $8-15$ degrees, while the morphology of the beach is sandy coral beaches and mangrove vegetated area.

Karampuang Island is a little village settlement, and land to use is only for household needs. The population of the island Karampuang as many as 2,937 people with the details of as many as 1,431 female and male soul as much as 1,506 people, the number of households 650 households, with a density of population of 46 inhabitants / km2 (BPS, 2016).

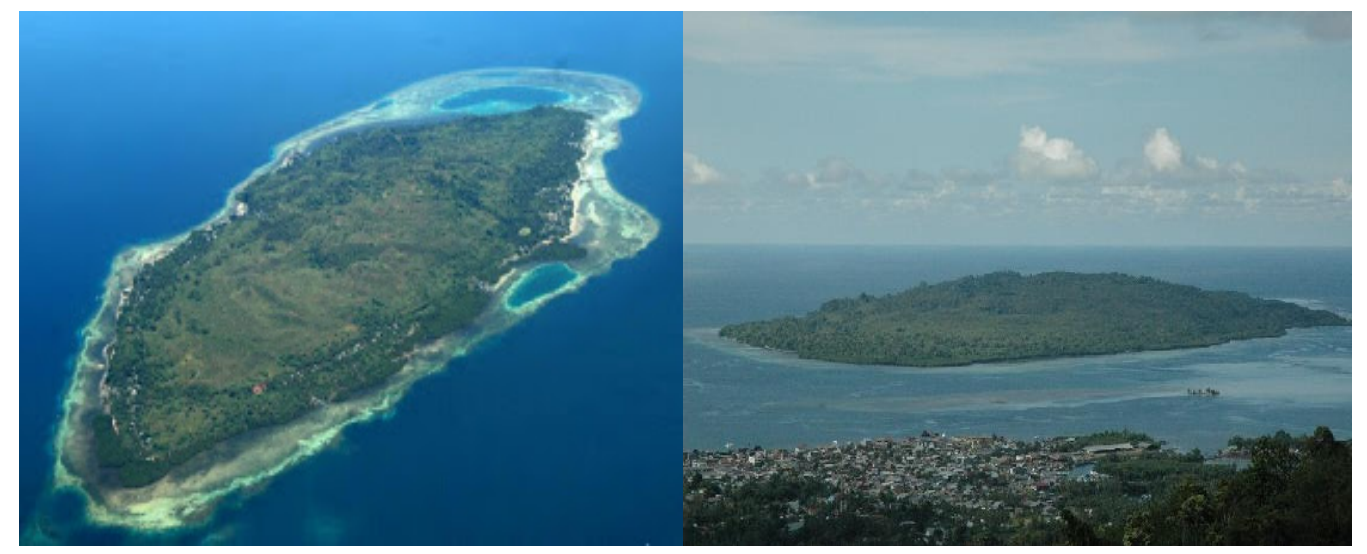

Figure 1. Karampuang Island seen from air and from Mamuju

The state of both acreage and production of paddy and upland rice in Mamuju district can be seen in the following table.

Table 1. Harvested Area, Production and Average Rice Production In Mamuju regency

\begin{tabular}{cccccccc}
\hline \multirow{2}{*}{ No } & \multirow{2}{*}{ Year } & \multicolumn{2}{c}{ Harvested Area (Ha) } & \multicolumn{2}{c}{ Production (Ton) } & \multicolumn{2}{c}{ Average (quintal/Ha) } \\
\cline { 3 - 8 } & & Rice & Upland rice & Rice & Upland rice & Rice & Upland rice \\
\hline 1 & 2010 & 26.898 & 2.729 & 134.708 & 7.997 & 50.08 & 29,3 \\
2 & 2011 & 28.376 & 2.769 & 142.390 & 8.168 & 50.18 & 29,5 \\
3 & 2012 & 30.835 & 2.628 & 151.584 & 10.627 & 49.85 & 29,29 \\
4 & 2013 & 17.179 & 2.040 & 87.520 & 5.979 & 50.95 & 29.30 \\
\hline
\end{tabular}

Source: Central Bureau of Statistics Mamuju, 2016

Rice harvested area in Mamuju during the interval between 2010-2012 increased by to $5-8 \%$, but in 2013 decreased approximately $44.3 \%$ in the cropped area. Whereas upland rice is grown in the mountainous regions harvested area is more likely to stagnate. The average rice production of 50 quintals per hectare each year.

\section{Results and Discussion}

\subsection{Food Production Patterns in Coastal Area}

Karampuang Island communities in adapting themselves to the geographical condition with the only livelihood as farmers, fishermen, and carpenters. Limited land 
both from the quantity of land (narrow area) and the quality of land generally dry land and partially rocky, so that people rely on farming and fishing. Farming Society just planted two commodities namely cocoa (Theobroma cocoa) and cassava (Manihot utilissima). The cocoa crop is planted with hilly land with a slope of 8-15 degrees. Whereas cassava plants grown in home gardens, the soil structure is dominated by a rock that cassava is produced to include cassava which is different from most cassava.

The description shows that most farms in the research site are in the category of marginal land. Marginal land, including land that cannot be used for farming because it is a land that is not productive (Annonimous, 2012). Limitations of the land became a very influential factor in economic activity. Commodity options are taken only as an alternative form of society adaptability to the environment.

Fishermen as a livelihood for both communities also have limitations regarding seasons and gear as well as a fleet that used to be very traditional. Fishing gear used is just a fishing line, trawl, spears, and traps so that the number of catches is still very limited. Fishing activity is only carried out during the day, with catches in the category of stonefish or pelagic fish such as the Napoleon wrasse and groupers.

Based on the above empirical fact that the fishermen on the island Karampuang are a fisherman who is still small fishing category is characterized by the low number of fishing gear and technology in fleet use (Salman, 2012). Culturally, a small fishing community still subsistence oriented. Where small fisherman more use of labor in the family (Mubyarto. dkk, 1984; Satria, 2001). As is the case of coastal communities with social conditions that describe the economic gap and farming system sub-systems, the limitations of the limiting factors of production for food production activities people on the island Karampuang. To provide food for the necessities of life is done traditionally.

A worker also is the livelihood of most people in the island Karampuang. For people that do/did not have agricultural land and did not choose fishing as a livelihood, prefer to be laborers in Mamuju. In adding to household income Karampuang Island communities, they want to be laborers. For men tend to become construction workers or porters, while women choose to become a good helper as a washerwoman and as shopkeepers. All work is done by part-time. So that people can be reunited with the family at night.

Based on the three principal occupations Karampuang Island communities over, then to meet the unique needs of food is very limited. This is due to limited land beside production also catchment area because they do not have a high-capacity motorboat. So the pattern of food production is carried out divided by two is 1). People who pursue their own Karampuang island food needs only in their yards, with an average area of $50.8 \mathrm{~m} 2$ yard area per household. Generally, food crops cultivated are manioc (cassava). Cassava plants grown by people on the island Karampuang have differences between potatoes in general, Ie the short form and a somewhat bitter taste. As for the need for such fish is done by catching fish in the sea, the fish caught is a pelagic fish or fish stone, and 2). Limitations in pursuit of their own against the people's food need Karampuang Island to make them get only by way of purchase such as rice, vegetables, and others. Point of a sale of both people's food stall - stall retailers as well as to the traditional markets in the city Mamuju. The pattern of food production, especially rice by Karampuang Island communities is particularly vulnerable to the risk of noncompliance regarding quantity. It is caused by public access to the market is very 
limited, and the increase in prices led to lower buying power. The limitation occurs because of the accessibility of means of transport available only motor boats which do not operate all the time so that retailers are an alternative. The low purchasing power caused food prices by retailers relatively high, so the amount of food purchased adjust the price.

\subsection{Food Consumption Patterns in Coastal Area}

Food Consumption Patterns people on the island Karampuang, as in general that in the mean consumption is related to the amount and type of food consumed by the community (Baliwati \& Roosita, 2004). The amount of food consumed by people on the island Karampuang is varied based on availability, due to limited public access to food, so food consumed depends on what is available (Wenkam, 1979). So also with the type of food or variations other than determined by availability, is also determined by the culture of the island of Karampuang (Soehardjo, 2006). In addition to the type and amount of food, eat intensity is also an element of the diet of people in the island Karampuang.

The type and amount of food consumed by the island people Karampuang for rice generally range of 9.3 to $11.3 \mathrm{~kg} / \mathrm{kcal} / \mathrm{months}$, while for cassava ranged from 2.8 to 3.4 $\mathrm{kg} / \mathrm{kcal} / \mathrm{months}$. As for the consumption of fresh fish to the average consumption Karampuang Island community as much as 1.2 to $1.6 \mathrm{~kg} / \mathrm{kcal} / \mathrm{month}$, chicken eggs (race and not a race) ranged from 0.4 to $0.6 \mathrm{~kg} / \mathrm{kcal} /$ month, Meat (chicken and beef) ranges from 0.2 to $0.4 \mathrm{~kg} / \mathrm{kcal} /$ month. Changes in the amount of food that was significant only when there are good bridal party or event akikah. The frequency or intensity of the meal by Karampuang Island community an average of 3 times a day, ie, morning (breakfast) range from $07.00-09.00 \mathrm{pms}$ (lunch) ranges from 11: 30 to 12: 30 and dinner (dinner) ranges at 19: 00 to 20: $00 \mathrm{pm}$.

Based on the above empirical description, it shows that consumption patterns of Island Karampuang parsed in three things: the type, amount and frequency. By nature, Karampuang Island people only consume rice as a staple food daily, while cassava is used as food alternative. Selection of both types of food is due to nutritional factors, the price, and the time factor (Osman et al., 2014).

Dietary factors, rice is an ingredient meal containing carbohydrates are high (Ackerman, Craft, \& Townsend, 2016; Rodriguez-Illera, Nikiforidis, van der Goot, \& Boom, 2016). Nutrients contained in the food will undergo biological processes after entry into the body and influence the functioning of body organs. The price factor, the budget allocation for the purchase of food needs available (Barigozzi, Alessi, Capasso, \& Fagiolo, 2012; Mao \& Xu, 2014). The budget allocation is determined by the income earned by the society; it is because of a higher proportion of the budget allocated to the food than for other needs. Thus the increase in revenue will determine the quantity and quality of food consumed.

As for the time factor, because most mothers of households in the island Karampuang work outside the home, so little time spent to diversify food (Osman et al., 2014). Diet Karampuang Island communities have also experienced a shift to fast food. This is because many women (housewives) who work in the informal sector, that is as a helper in Mamuju, so less have time to cook in the morning. The impact is most breakfasts using rice and instant noodles, Instant noodles used as a substitute for 
vegetables because cooking vegetables requires a relative rather old. Also, the work pressure is forcing many workers to keep working until late at night. While the hunger for energy is drained, then the choice of fast food.

In addition to these factors, the ability of local cooking (Gastronomy) and its uniqueness is also a driving factor of selecting cassava as a food alternative (Mak, Lumbers, \& Eves, 2012). Cassava into traditional food which is the cultural heritage of the island of Karampuang. The food is typical name Jepa (Mandar language) or Kalumpang (Mamuju language), where cassava is the main ingredient. Jepa or Kalumpang usually consumed by people with typical Mamuju cook fish or dried fish. The food is one form of diversification by society.

\section{Conclusion}

Food production patterns of the island Karampuang characterized by the production of a limited form of cassava were only able to complement the food needs. This is due to limited production factors of land for agriculture and fleets and fishing gear for the fisheries sector. Land in the Karampuang island is marginal land, plants are able to grow cassava. While in the fisheries sector in general Karampuang Island community is a traditional fishing fleet and fishing gear are simple. The existence of institutional traders, in particular, plays an important role, because people generally buy food needs of merchants.

Food consumption patterns of Karampuang Island is marked by the intensity of the low consumption, low consumption type material variations; this is due to the limitations of public access to food so that the food consumed only locally based as cassava. Also, the diet of people a bit of a shift to fast food caused by the busyness housewife working in the informal sector and the pressures on work with a long duration.

\section{Acknowledgements}

We would like to thank the Agricultural Extension Workers and all people on the island Karampuang, for their help and participation.

\section{References}

Ackerman, D. L., Craft, K. M., \& Townsend, S. D. (2016). Infant food applications of complex carbohydrates: Structure, synthesis, and function. Carbohydrate Research. https://doi.org/10.1016/j.carres.2016.11.007

Ahmad, A., Rahmadanih, Ali, M. Saleh. S. (2017). Patterns of Food Consumption and Production of Mountainous Community in Sinjai District, South Sulawesi Province , Indonesia. International Journal of Agriculture System (IJAS) Patterns, 5(1), 90-100. https://doi.org/http://dx.doi.org/10.20956/ijas.v5i1.1175

Ali, M. Saleh. S., Majjka, A. A., \& Salman, D. (2017). Food Consumption and Production in Tempe Lake, South Sulawesi, Indonesia. Asian Ruarl Study, 1(1), 43-52.

Anonimous. (2012). Agrofuels and the myth of marginal lands. The Gaia Foundation.

Arifin, B. (2004). Analisis Ekonomi Pertanian Indonesia. Jakarta: Penerbit Buku Kompas. 
Baliwati, Y., \& Roosita, K. (2004). Sistem Pangan dan Gizi dalam Pengantar Pangan dan Gizi. (C. D. (eds) YF Baliwati, A Khom- san, Ed.). Jakarta: Penebar Swadaya.

Barigozzi, M., Alessi, L., Capasso, M., \& Fagiolo, G. (2012). The distribution of household consumption-expenditure budget shares. Structural Change and Economic Dynamics, 23(1), 69-91. https://doi.org/10.1016/j.strueco.2011.09.003

Boucekkine, R., Prieur, F., \& Puzon, K. (2016). On the timing of political regime changes in resource-dependent economies. European Economic Review, 85, 188207. https://doi.org/10.1016/j.euroecorev.2016.02.016

BPS. (2016). Kabupaten Mamuju dalam Angka. Badan Pusat Statistik Kabupaten Mamuju.

Brizga, J., Mishchuk, Z., \& Golubovska-Onisimova, A. (2014). Sustainable consumption and production governance in countries in transition. Journal of Cleaner Production, 63, 45-53. https://doi.org/10.1016/j.jclepro.2013.06.011

Cohen, B., \& Mu, P. (2015). Sharing cities and sustainable consumption and production : towards an integrated framework. Journal of Cleaner Production, 111. https://doi.org/10.1016/j.jclepro.2015.07.133

Diamond, J. (2005). Collapse. Journal of Chemical Information and Modeling (Vol. 53). New York: Viking Penguin. https://doi.org/10.1017/CBO9781107415324.004

Dubey, R., Gunasekaran, A., Childe, S. J., Papadopoulos, T., Wamba, S. F., \& Song, M. (2016). Towards a theory of sustainable consumption and production: Constructs and measurement. Resources, Conservation and Recycling, 106, 78-89. https://doi.org/10.1016/j.resconrec.2015.11.008

Geels, F. W., Mcmeekin, A., Mylan, J., \& Southerton, D. (2015). A critical appraisal of Sustainable Consumption and Production research: The reformist, revolutionary and reconfiguration positions. Global Environmental Change, 34, 1-12. https://doi.org/10.1016/j.gloenvcha.2015.04.013

Jonkute, G., \& Staniškis, J. K. (2016). Realising Sustainable Consumption and Production in companies: the SURESCOM model. Journal of Cleaner Production, (Jonkute, G., Staniškis, J. K. (2016). AC SC. Journal of Cleaner Production. https://doi.org/10.1016/j.jclepro.2016.03.176). https://doi.org/10.1016/j.jclepro.2016.03.176

Mao, R., \& Xu, J. (2014). Population aging, consumption budget allocation and sectoral growth. China Economic Review, 30, 44-65. https://doi.org/10.1016/ j.chieco.2014.05.004

Menike, L. M. C. S., \& Arachchi, K. A. G. P. K. (2016). Adaptation to Climate Change by Smallholder Farmers in Rural Communities: Evidence from Sri Lanka. Procedia Food Science, 6(Icsusl 2015), 288-292. https://doi.org/10.1016/ j.profoo.2016.02.057

Meskhia, I. E. (2016). Food security problems in post Soviet Georgia. Annals of Agrarian Science, 14(2), 46-51. https://doi.org/10.1016/j.aasci.2016.03.004

Mubyarto. dkk. (1984). Nelayan dan Kemiskinan; Studi Antropologi di Dua Desa Pantai. Jakarta: Rajawali Press.

Osman, I., Osman, S., Mokhtar, I., \& Setapa, F. (2014). Family Food Consumption: Desire towards Convenient Food Products. Procedia - Social and Behavioral Sciences, 121 (September 2012), 223-231. https://doi.org/10.1016/j.sbspro. 2014.01.1123 
Rodriguez-Illera, M., Nikiforidis, C. V., van der Goot, A. J., \& Boom, R. M. (2016). Exergy efficiency from staple food ingredients to body metabolism: the case of carbohydrates. Submitted for Publication. https://doi.org/10.1016/ j.jclepro.2016.10.009

Salman, D. (2012). Sosiologi Desa: Revolusi Senyap dan Tarian Kompleksitas,. Makassar: Penerbit Ininnawa.

Satria, A. (2001). Dinamika modernisasi perikanan: formasi sosial dan mobilitas nelayan (1st ed.). Bandung: Humaniora Utama Press. Retrieved from https://catalogue.nla.gov.au/Record/86171

Satria, A. (2009). Ekologi Politik Nelayan. (A. Solihin, Ed.) (1st ed.). Yogyakarta: LKIS Printing Cemerlang.

Satria, Matsuda, Y., \& Sano, M. (2006). Contractual solution to the tragedy of property right in coastal fisheries. Marine Policy, 30(3), 226-236. https://doi.org/10.1016/j.marpol.2005.01.003

Soehardjo. (2006). Pangan Gizi dan Pertanian. Jakarta: Universitas Indonesia Press.

Wan, G. H. (2005). Convergence in food consumption in Rural China: Evidence from household survey data. China Economic Review, 16(1), 90-102. https://doi.org/10.1016/j.chieco.2004.09.002

Wenkam. (1979). Nutritional Aspects Of Some Tropical Plant Foods. Tropical Food: Chemistry and Nutrition, 341-350. https://doi.org/http://dx.doi.org/10.1016/B978$0-12-370902-8.50005-8$ 